\title{
Language of the Sea: \\ Ideologies within Kabar Dari Laut by Chairil Anwar
}

\author{
Jumanto \\ Faculty of Humanities, Universitas Dian Nuswantoro, Semarang
}

\begin{abstract}
This research paper explores ideologies contained in the Received: 1946 poem Kabar Dari Laut by Chairil Anwar. The main 1 July 2018 words Kabar and Laut are central in this poem. This interpretive exploration tries to find out the ideologies contained in the phrase Kabar (literally means news, however, it also rather to say story) and the ideology in the scripture of laut [the sea] and how the two sets of expressions speak out the restlessness of the noted poet Chairil Anwar. The research findings have shown that the news and the sea have been used by the frustrated author to

Revised:

8 August 2018

Accepted:

8 November 2018

Corresponding author:

ilhamj@dsn.dinus.ac.id speak out his regret, awareness, and hatred due to his broken-hearted soul upon his ex-lover in the past. The findings also show that the sea signifies the author's small self to face and live in this abundant life (the sea). His hatred towards his ex-lover has remained sad memories and bad realities which the author bears in his time while he is writing the poem.
\end{abstract}

Keywords: Chairil Anwar; Kabar Dari Laut, Language of the Sea; Ideology.

\section{Introduction}

Seas have been vastly elaborated in some professional works of academic scholars, or even literary workers. One noted circle of the literary workers is called that of poets. A poet is one who is working on poetry or creates poems to explore life on earth, living in the world or even the realms of the afterlife. Poetry is then closely related with poets who create poems. Poetry is writing that formulates a concentrated imaginative awareness of experience in language chosen and arranged to generate a specific emotional response through meaning, sound, and rhythm, ${ }^{1}$ literary work in which the expression of feelings and ideas is given intensity by the use of distinctive style and rhythm; poems collectively or as a genre of literature, ${ }^{2}$ or poems in general as a form of literature. ${ }^{3}$ A poet then refers to one who writes poetry: a maker of verses, or a person who writes poems. The product of poetry through the creation by a poet is then called a poem. It is a composition in verse, a piece of writing in which the expression of feelings and ideas is given intensity by particular attention to diction (sometimes involving rhyme), rhythm, and imagery, or a piece of writing in which the words are arranged in separate lines, often ending in rhyme, and are chosen for their sound and for the images and ideas they suggest.

${ }^{1}$ Merriam-Webster, Merriam-Webster's Dictionary of Synonyms (New York: Merriam-Webster Inc., 1968).

${ }^{2}$ Angus Stevenson, Oxford Dictionary of English (Oxford: Oxford University Press, 1968).

${ }^{3}$ Cambridge, Cambridge Dictionary, https://dictionary.cambridge.org/dictionary/english, accessed on 15 June 2018. 
Chairil Anwar is one of the great Indonesian poets, born in Medan, North Sumatera, on 26 Juli 1922 and passing away in Jakarta, on 28 April 1949, reaching the very young age 26. He has been noted as binatang jalang (a wild animal), partly excerpted from his poem $A k u$, a poem of his rebelling passion. He is a noted poet in Indonesia, for he has produced about 96 works, the 70 of which are poems. Jassin has crowned Chairil Anwar along with Asrul Sani and Rivai Apin as the pioneers of modern poetry as well as Angkatan 45 in Indonesia. ${ }^{4}$ The poems of Chairil Anwar include various themes or topics, i.e., individualism, deaths, rebellions, and existentialism, which are often multi-interpreted. Kabar Dari Laut (1946) is one of the famous Indonesian poems of Chairil Anwar.

The poem Kabar Dari Laut (1946) was firstly published in Pantja Raja on 15 January 1947 in the Chairil Anwar's collection of Deru Campur Debu. This poem is unique, as it concerns the sea, of which as cited above, waters and seas are everywhere in the Indonesian archipelago, and as the poem is probably multi-interpreted. So popular is it that in one occasion, Susi Pudjiastuti, the Indonesian Minister of Maritime Affairs and Fisheries, has recited the poem in celebrating Chairil Anwar through speeches, musicals, and poetry reading, in Tempo Office, Jakarta, on 15 August 2016. However, is this poem indeed about the sea? Is the news indeed about everything about the sea? What are the exact meanings of the story and the sea? What are the ideologies Chairil Anwar has tried to expose to and tell the world? These are questions this paper is exploring. These are questions to be answered by this paper entitled Language of the Sea: Ideologies within Kabar Dari Laut by Chairil Anwar.

This study on a noted poem by Chairil Anwar is an interpretive descriptive qualitative one, trying to find out the ideologies contained in Kabar dari Laut through interpretive techniques. The researcher observes the poem and interprets the ideologies in a structured form. The ideologies upon the interpretive methods are then analyzed through a coding technique, consisting of three steps: open coding, axial coding, and selective coding. ${ }^{5}$

In the open coding, the data in the form of revealed ideologies are listed and separated. The separated data are then reunited in the axial coding to come to significant categories. The selective coding then discovers the main or the core ideologies, i.e., a storyline built by relating the major groups from the axial coding. The analysis of ideologies in the coding technique for this research consists of cycles. The cycle is a course or series of events or operations that recur regularly and usually lead back to the starting point. It starts from the general to more particular, and then end in the core of ideologies. It is the core cycle which is the close interpretationas the fundamental expressions of the poem Kabar Dari Laut (1946) by Chairil Anwar.

Ideology is a variant of meaning. The ideologies to be revealed in Kabar Dari Laut are interpreted based on the Semiotics. Semiotics is of two great schools, i.e., the Saussurian and the Peircian. The Saussurian semiotics is then more noted as semiology, and the Peircian semiotics remains semiotics. The Saussurian semiology suggests that a sign is a dyadic entity, while the Peircian semiotics views a flag as a triadic entity, i.e., index, icon, and symbol. Semiotics involves the study of signs and sign processes, indication, designation, likeness,

${ }^{4}$ H.B. Jassin, Kesusastraan Indonesia Modern dalam Kritik dan Esei (Jakarta: Gunung Agung, 1967). See also H.B. Jassin, Angkatan 45 (Jakarta: Jajasan Dharma, 1972).

${ }^{5}$ A. Strauss and J. Corbin, Basics of Qualitative Research: Grounded Theory Procedures and Techniques (California: Sage Publications, 1990). See also A. Bohm "Theoretical Coding: Text Analysis in Grounded Theory", in U. Flick, E. Kardorff \& I. Steinke (eds.), A Companion to Qualitative Research (London: SAGE Publications, 2004). Johnny Saladana, The Coding Manual for Qualitative Researchers (London: SAGE Publications Ltd., 2012). 
analogy, allegory, metonymy, metaphor, symbolism, signification, and communication. A popular advocation of Semiotics is Umberto Eco with his work A Theory of Semiotics (1975). ${ }^{6}$ There is much concern on semiotics, anthropological, and sociological dimensions, e.g., the Italian semiotician and novelist Umberto Eco proposing that every cultural phenomenon might be studied as communication. ${ }^{7}$

Roland Barthes advocating the Saussurian school of semiotics has spent the early 1960s exploring the fields of semiology and structuralism, especially under his work Mythologies. ${ }^{8}$ In this context of his study, Barthes observes and analyzes daily items as containing ideologies and myths. Barthes uses the term myth while examining the popular, consumer culture of post-war France to reveal that objects were organized into meaningful relationships via narratives that expressed collective cultural values. ${ }^{9}$ In this research, ideologies are revealed through interpretive techniques from the expressions or words in the poem Kabar Dari Laut, which contain cultural values, as data of the research.

\section{The Potential Ideologies in the Open Coding on Kabar Dari Laut}

The potential ideologies in the poem Kabar dari Laut revealed through interpretive techniques as the result of open coding are listed in Table 1.

Table 1. The Potential Ideologies as Tokens in the Open Coding on Kabar Dari Laut

\begin{tabular}{|c|c|c|c|}
\hline No. & Lines & Ideologies & Notes \\
\hline 1 & $\begin{array}{l}\text { Aku memang benar tolol ketika itu [I } \\
\text { was a real real fool then] }\end{array}$ & stupidity and regret & $\begin{array}{l}\text { Tolol ketika itu; aku } \\
\text { memang benar [a real } \\
\text { real fool then; I was] }\end{array}$ \\
\hline 2 & $\begin{array}{l}\text { Mau pula membikin hubungan dengan } \\
\text { kau; [willin' to make love with you] }\end{array}$ & sad memory & $\begin{array}{l}\text { Hubungan dengan } \\
\text { kau [make love with } \\
\text { you] }\end{array}$ \\
\hline 3 & $\begin{array}{l}\text { Lupa kelasi tiba-tiba bisa sendiri di laut } \\
\text { pilu [forgettin' as sailor, suddenly lonely } \\
\text { in this sad sad sea] }\end{array}$ & $\begin{array}{l}\text { awareness and } \\
\text { sad reality }\end{array}$ & $\begin{array}{l}\text { Lupa kelasi; sendiri di } \\
\text { laut pilu forgettin' as } \\
\text { sailor; [lonely in this } \\
\text { sad sad sea] }\end{array}$ \\
\hline 4 & $\begin{array}{l}\text { Berujuk kembali dengan tujuan biru } \\
\text { [made up back, along with a sad course] }\end{array}$ & $\begin{array}{l}\text { awareness and } \\
\text { sad reality }\end{array}$ & $\begin{array}{l}\text { Berujuk; tujuan biru } \\
\text { [made up back; a sad } \\
\text { course] }\end{array}$ \\
\hline 5 & $\begin{array}{l}\text { Di tubuhku ada luka sekarang [Now } \\
\text { with a wound in my body] }\end{array}$ & $\begin{array}{l}\text { awareness and } \\
\text { sad reality }\end{array}$ & $\begin{array}{l}\text { Di tubuhku ada luka } \\
\text { [a wound in my body] }\end{array}$ \\
\hline 6 & $\begin{array}{l}\text { bertambah lebar juga, mengeluar darah, } \\
\text { severely bad, bleeding }\end{array}$ & $\begin{array}{l}\text { awareness and } \\
\text { sad reality }\end{array}$ & $\begin{array}{l}\text { bertambah lebar, } \\
\text { mengeluar darah } \\
\text { [severely bad; } \\
\text { bleeding] }\end{array}$ \\
\hline 7 & $\begin{array}{l}\text { di bekas dulu kau cium napsu dan } \\
\text { garang; } \\
\text { the spot you kissed and made lust to me; }\end{array}$ & $\begin{array}{l}\text { awareness and } \\
\text { sad memory }\end{array}$ & $\begin{array}{l}\text { dulu kau cium napsu } \\
\text { dan garang [you } \\
\text { kissed and made lust } \\
\text { to me] }\end{array}$ \\
\hline
\end{tabular}

\footnotetext{
${ }^{6}$ Umberto Eco, A Theory of Semiotics (Bloomington: Indiana University Press, 1975).

${ }^{7}$ M. Caesar, Umberto Eco: Philosophy, Semiotics, and the Work of Fiction (Oxford: Wiley-Blackwell, 1999). ${ }^{8}$ Roland Barthes, Mythologies, a translation by Annette Lavers (1972) (France: Les Lettres Nouvelles, 1957). ${ }^{9}$ D.J. Huppatz, "Roland Barthes, Mythologies", Design and Culture 3, 1 (2011).
} 


\begin{tabular}{|c|c|c|c|}
\hline 8 & $\begin{array}{l}\text { lagi aku pun sangat lemah serta } \\
\text { menyerah. } \\
\text { it again made me in deep weak } \\
\text { surrender. }\end{array}$ & $\begin{array}{l}\text { awareness and } \\
\text { sad reality }\end{array}$ & $\begin{array}{l}\text { sangat lemah; serta } \\
\text { menyerah [in deep } \\
\text { weak surrender] }\end{array}$ \\
\hline 9 & $\begin{array}{l}\text { Hidup berlangsung antara buritan dan } \\
\text { kemudi. } \\
\text { Life lasts between stern and steer. }\end{array}$ & $\begin{array}{l}\text { awareness and } \\
\text { sad reality }\end{array}$ & $\begin{array}{l}\text { hidup; buritan dan } \\
\text { kemudi [life; stern } \\
\text { and steer] }\end{array}$ \\
\hline 10 & $\begin{array}{l}\text { Pembatasan cuma tambah menjatuhkan } \\
\text { kenang. } \\
\text { The limit of it invited memory sheer. }\end{array}$ & $\begin{array}{l}\text { awareness and } \\
\text { sad memory }\end{array}$ & $\begin{array}{l}\text { pembatasan; } \\
\text { menjatuhkan kenang } \\
\text { [the limit; invited } \\
\text { memory sheer] }\end{array}$ \\
\hline 11 & $\begin{array}{l}\text { Dan tawa gila pada whisky tercermin } \\
\text { tenang. } \\
\text { And whisky laughters of madness, } \\
\text { so pacifying. }\end{array}$ & $\begin{array}{l}\text { awareness and } \\
\text { sad reality }\end{array}$ & $\begin{array}{l}\text { tawa gila; whisky; } \\
\text { tenang [laughters of } \\
\text { madness, whisky; so } \\
\text { pacifying] }\end{array}$ \\
\hline 12 & $\begin{array}{l}\text { Dan kau? Apakah kerjamu sembahyang } \\
\text { dan memuji, } \\
\text { And you? Now always praying and } \\
\text { praising, }\end{array}$ & $\begin{array}{l}\text { hatred and } \\
\text { mockery }\end{array}$ & $\begin{array}{l}\text { kau?; sembahyang } \\
\text { dan memuji (?) } \\
\text { [you?; praying and } \\
\text { praising (?)] }\end{array}$ \\
\hline 13 & $\begin{array}{l}\text { Atau di antara mereka juga terdampar, } \\
\text { Or, the same you, stranded among them, }\end{array}$ & $\begin{array}{l}\text { hatred and } \\
\text { mockery }\end{array}$ & $\begin{array}{l}\text { (kau) terdampar } \\
\text { [(you) stranded] }\end{array}$ \\
\hline 14 & $\begin{array}{l}\text { Burung mati pagi hari di sisi sangkar? } \\
\text { A dead bird beside cage in the morning? }\end{array}$ & $\begin{array}{l}\text { hatred and } \\
\text { mockery }\end{array}$ & $\begin{array}{l}\text { (kau) burung mati; di } \\
\text { sisi sangkar }[(\text { you a a } \\
\text { dead bird; beside } \\
\text { cage] }\end{array}$ \\
\hline
\end{tabular}

Source: Interpretations by the Researcher

From the open coding through interpretive techniques on the expressions or words with cultural values in the poem Kabar Dari Laut, we have revealed 18 ideologies, i.e. (1) stupidity, (2) regret, (3) sad memory, (4) awareness, (5) sad reality, (6) awareness, (7) sad reality, (8) awareness, (9) sad reality, (10) awareness, (11) sad reality, (12) awareness, (13) sad memory, (14) awareness, (15) sad reality, (16) awareness, (17) sad reality, (18) awareness, (19) sad memory, (20) awareness, (21) sad reality, (22) hatred, (23) mockery, (24) hatred, (25) mockery, (26) hatred, and (27) mockery. This open coding is listing all the potential ideologies revealed and taken for granted from the poem. We can see that some ideologies repeat, and some others do not. It has been revealed through interpretive techniques in the poetry can be accounted for as follows: (1) The ideologies stupidity and regret in the first line have been published from tolol ketika itu and aku memang benar respectively; (2) The ideology sad memory in the second line has been shown from hubungan dengan kau; (3) The ideologies awareness and sad reality in the third line have been revealed from lupa kelasi and sendiri di laut pilu respectively; (4) et cetera. The result of interpretive techniques in this open coding is basically all the tokens of the research that serve as the data for the next or further coding analyses, i.e. the axial coding and the selective coding.

\section{The Classified Ideologies in the Axial Coding on Kabar dari Laut}

The core ideology in this study is on the poem Kabar Dari Laut are to be found out through a coding technique, especially in the second and third coding analyses. In the axial coding, 
types of ideologies are identified based on their interpreted classification. As have been accounted for in the previous open coding, the result of interpretive techniques, hence the identified tokens already obtained. It serves the further coding analyses, i.e., the axial coding and selective coding. In this sense of axial coding, we are then focusing on types of ideologies revealed in the opening code via interpretive techniques. The types of ideologies in the axial coding can be seen in Table 2 .

From the axial coding through classification on the expressions or words with cultural values and their revealed ideologies in the poem Kabar dari Laut, we have come to 8 types of ideologies, i.e. (1) stupidity and regret, (2) sad memory, (3) awareness and sad reality, (4) sad memory, (5) awareness and sad reality, (6) awareness and sad memory, (7) awareness and sad reality, (8) hatred and mockery. This axial coding is listing types of ideologies through interpreted classification. We can also see that some ideologies still repeat, and some others do not. The ideologies that have been classified in this axial coding on the poem can be accounted for as follows. (1) The ideologies stupidity and regret in the first type have been revealed from tolol ketika itu and aku memang benar respectively; (2) The ideology sad memory in the second type has been revealed from hubungan dengan kau; (3) The ideologies awareness and sad reality in the third type have been revealed from lupa kelasi, berujuk, di tubuhku ada luka, bertambah lebar, and sendiri di laut pilu, tujuan biru, di tubuhku ada luka, mengeluar darah respectively; (4) The ideology sad memory in the fourth type has been revealed from dulu kau cium napsu dan garang; (5) The ideologies awareness and sad reality in the fifth type have been revealed from sangat lemah, hidup and serta menyerah, buritan dan kemudi respectively; (6) The ideologies awareness and sad memory in the sixth type have been revealed from pembatasan and menjatuhkan kenang respectively; (7) The ideologies awareness and sad reality in the seventh type have been revealed from tawa gila, whisky and tenang respectively; and (8) The ideologies hatred and mockery in the eighth type have been revealed from kau?, (kau) terdampar, (kau) burung mati and sembahyang dan memuji (?), (kau) terdampar, di sisi sangkar respectively.

The result of classification of ideologies into types in this axial coding serves the selective coding on major ideologies in the next or further coding analysis.

Table 2. The Classified Ideologies as Types in the Axial Coding on Kabar dari Laut

\begin{tabular}{|c|c|c|c|}
\hline No. & Lines & Classified Ideologies & Notes \\
\hline 1 & $\begin{array}{l}\text { Aku memang benar tolol ketika itu [I } \\
\text { was a real real fool then] }\end{array}$ & $\begin{array}{l}\text { Stupidity and regret } \\
\text { (1) }\end{array}$ & $\begin{array}{l}\text { Tolol ketika itu; aku } \\
\text { memang benar [a real real } \\
\text { fool then; I was] }\end{array}$ \\
\hline 2 & $\begin{array}{l}\text { Mau pula membikin hubungan dengan } \\
\text { kau; [willin' to make love with you] }\end{array}$ & $\begin{array}{l}\text { Sad memory } \\
\text { (2) }\end{array}$ & $\begin{array}{l}\text { Hubungan dengan kau } \\
\text { [make love with you] }\end{array}$ \\
\hline 3 & $\begin{array}{l}\text { Lupa kelasi tiba-tiba bisa sendiri di laut } \\
\text { pilu [forgettin' as sailor, suddenly lonely } \\
\text { in this sad sad sea] }\end{array}$ & & $\begin{array}{l}\text { Lupa kelasi; sendiri di laut } \\
\text { pilu [forgettin' as sailor; } \\
\text { lonely in this sad sad sea] }\end{array}$ \\
\hline 4 & $\begin{array}{l}\text { Berujuk kembali dengan tujuan biru } \\
\text { [made up back, along with a sad course] }\end{array}$ & & $\begin{array}{l}\text { Berujuk; tujuan biru } \\
\text { [made up back; a sad course] }\end{array}$ \\
\hline 5 & $\begin{array}{l}\text { Di tubuhku ada luka sekarang [Now } \\
\text { with a wound in my body] }\end{array}$ & $\begin{array}{l}\text { Awareness and sad } \\
\text { reality }\end{array}$ & $\begin{array}{l}\text { Di tubuhku ada luka } \\
\text { [a wound in my body] }\end{array}$ \\
\hline 6 & $\begin{array}{l}\text { Bertambah lebar juga, mengeluar darah } \\
\text { [severely bad, bleeding] }\end{array}$ & (3) & $\begin{array}{l}\text { Bertambah lebar; mengeluar } \\
\text { darah } \\
\text { [severely bad; bleeding] }\end{array}$ \\
\hline
\end{tabular}




\begin{tabular}{|c|c|c|c|}
\hline 7 & $\begin{array}{l}\text { Di bekas dulu kau cium napsu dan } \\
\text { garang [the spot you kissed and made } \\
\text { lust to me]; }\end{array}$ & $\begin{array}{l}\text { Sad memory } \\
\text { (4) }\end{array}$ & $\begin{array}{l}\text { Dulu kau cium napsu dan } \\
\text { garang [you kissed and } \\
\text { made lust to me] }\end{array}$ \\
\hline 8 & $\begin{array}{l}\text { Lagi aku pun sangat lemah serta } \\
\text { menyerah [it again made me in deep } \\
\text { weak surrender]. }\end{array}$ & $\begin{array}{l}\text { Awareness and sad } \\
\text { reality }\end{array}$ & $\begin{array}{l}\text { Sangat lemah; serta } \\
\text { menyerah } \\
\text { [in deep weak surrender] }\end{array}$ \\
\hline 9 & $\begin{array}{l}\text { Hidup berlangsung antara buritan dan } \\
\text { kemudi [Life lasts between stern and } \\
\text { steer]. }\end{array}$ & $(5)$ & $\begin{array}{l}\text { Hidup; buritan dan kemudi } \\
\text { [life; stern and steer] }\end{array}$ \\
\hline 10 & $\begin{array}{l}\text { Pembatasan cuma tambah menjatuhkan } \\
\text { kenang [the limit of it invited memory } \\
\text { sheer] }\end{array}$ & $\begin{array}{l}\text { Awareness and } \\
\text { sad memory } \\
\text { (6) }\end{array}$ & $\begin{array}{l}\text { Pembatasan; menjatuhkan } \\
\text { kenang } \\
\text { [the limit; invited memory } \\
\text { sheer] }\end{array}$ \\
\hline 11 & $\begin{array}{l}\text { Dan tawa gila pada whisky tercermin } \\
\text { tenang [And whisky laughters of } \\
\text { madness, so pacifying] }\end{array}$ & $\begin{array}{l}\text { Awareness and sad } \\
\text { reality } \\
\text { (7) }\end{array}$ & $\begin{array}{l}\text { Tawa gila; whisky; tenang } \\
\text { [laughters of } \\
\text { madness, whisky; so } \\
\text { pacifying] }\end{array}$ \\
\hline 12 & $\begin{array}{l}\text { Dan kau? Apakah kerjamu sembahyang } \\
\text { dan memuji [And you? Now always } \\
\text { praying and praising] }\end{array}$ & & $\begin{array}{l}\text { Kau?; sembahyang } \\
\text { dan memuji (?) } \\
\text { [you?; praying and } \\
\text { praising (?)] }\end{array}$ \\
\hline 13 & $\begin{array}{l}\text { Atau di antara mereka juga terdampar } \\
\text { [or, the same you, stranded among them] }\end{array}$ & $\begin{array}{l}\text { Hatred and mockery } \\
\text { (8) }\end{array}$ & $\begin{array}{l}\text { (Kau) terdampar } \\
\text { [(you) stranded] }\end{array}$ \\
\hline 14 & $\begin{array}{l}\text { Burung mati pagi hari di sisi sangkar? } \\
\text { [A dead bird beside cage in the } \\
\text { morning?] }\end{array}$ & & $\begin{array}{l}\text { (Kau) burung mati; di sisi } \\
\text { sangkar }[(\mathrm{you}) \text { a dead bird; } \\
\text { beside cage] }\end{array}$ \\
\hline
\end{tabular}

Source: Interpretations by the Researcher

\section{The Core Ideologies in the Selective Coding on Kabar Dari Laut}

The core ideologies in this study on the poem Kabar Dari Laut are to be found out through a coding technique, especially in the final coding analysis, i.e., the selective coding. The particular coding in this sense, as have been stated in the method, is carried out through cycles. The cycles refer to repeated types of ideologies revealed from their respective expressions or words in the poem Kabar Dari Laut, and the sequences are also identified through interpretive techniques by the researcher. To come to the core cycles or core ideologies of the poetry, we inductively employ several cycles, from general to particular. Employing several sequences in this sense means selecting the core ideologies which the researcher assumes as best describing the poem as the final finding of the research. The inductively-employed cycles based on classified ideologies or types of ideologies in Table 2 above are as follows ${ }^{10}(1)$ stupidity and regret $\rightarrow>$ sad memory $\rightarrow>$ awareness and sad reality $\rightarrow$ sad memory $->$ awareness and sad reality $\rightarrow>$ awareness and sad memory $\rightarrow>$ awareness and sad reality $\rightarrow$ hatred and mockery; (2) stupidity and regret $\rightarrow>$ sad memory $\rightarrow>$ awareness and sad reality $\rightarrow$ awareness and sad memory $\rightarrow$ hatred and mockery; (3) stupidity and regret $\rightarrow$ awareness and sad reality $\rightarrow>$ awareness and sad memory $\rightarrow$ hatred and mockery; (4) regret $\rightarrow>$

\footnotetext{
${ }^{10}$ The sign $->$ in this analysis is used to indicate the flow of ideologies in the cycle concerned.
} 
awareness and reality $\rightarrow$ awareness and sad memory $\rightarrow$ hatred; (5) regret $\rightarrow$ awareness $\rightarrow$ hatred.

We can see from the listing above that the researcher subjectively interprets the inductively-employed cycles of ideologies. There may be other different interpretations; however, the researcher has come to the listed sequences through his empirically-logical assumptions within his working knowledge as a researcher as well as an interpreter. The inductively-employed cycles have come to or ended in the core ideologies (regret $\rightarrow>$ awareness $\rightarrow$ hatred) and will serve as sufficient provision for discussion or accounts for the findings upon the coding-technique analyses.

\section{The Core Ideologies and Representations}

The core ideologies regret $->$ awareness $->$ hatred have been found out in this research on the poem Kabar Dari Laut (1946) by Chairil Anwar. The core ideology regret has represented the ideologies stupidity and regret itself in verse. Usually, indeed, one has done something stupid in the past and then regrets later. Disappointment in life indeed comes later than stupidity. It is what probably has happened to the author or the poet Chairil Anwar. He did some silliness in the past, i.e., Aku memang benar tolol ketika itu [I was a real fool then], and regrets in the present. It is the first core ideology in the poem.

The second core ideology awareness has represented various sub-ideologies, i.e., a sad memory, consciousness, sad reality, sad memory, awareness, sad reality, awareness, a sad memory, awareness, and sad reality. We can see that in this second core ideology, awareness, Chairil Anwar wants to expose his feelings or tells the world that he has done some stupidity in the past, and in the present time he is aware of its consequences, i.e., the sad memories are haunting him and smashing him to the ground of lousy reality he is facing while he is writing the poem. Sad memories and bad realities come to him, one after the other, and makes him terrible, i.e., frustrated, lost, and restless. The awareness of sad memory of heartbreak, which deeply frustrates him, is revealed in the expression hubungan dengan kau [make love with you]. The recognition that he is lost is revealed in the expressions lupa kelasi [forgettin' as sailor] and sendiri di laut pilu [lonely in this sad sea], forgetting who he is now and forgetting what he lives for, without love. The awareness of his restlessness is revealed from various expressions.

$$
\begin{aligned}
& \text { berujuk; tujuan biru [made up back; a sad course] } \\
& \text { di tubuhku ada luka [a wound in my body] } \\
& \text { bertambah lebar; mengeluar darah [severely bad; bleeding] } \\
& \text { dulu kau cium napsu dan garang [you kissed and made lust to me] } \\
& \text { sangat lemah; serta menyerah [in deep weak surrender] } \\
& \text { hidup; buritan dan kemudi [life; stern and steer] } \\
& \text { pembatasan; menjatuhkan kenang [the limit; invited memory sheer] } \\
& \text { tawa gila; whisky; tenang [laughters of madness, whisky; so pacifying] }
\end{aligned}
$$

With all these various expressions, Chairil Anwar wants the world to know about his restless feelings which always come to and go from his self or soul in form of bad memories and bad realities that he has to face in the present. All these are the sounds of broken-hearted feelings of Chairil Anwar. Then, what comes next after his regret and awareness? Does Chairil Anwar accept the bad memories and realities due to his stupid past? 
The third core ideology hatred is the answer. He does not accept his destiny, his bad memories and realities which come and stay in the present time of his life. He does not want to learn from the past. He blames his past, his ex-lover! This blame in form of hatred remains and stays in his restless heart. This blame is reflected in the hatred and mockery to his ex-lover, i.e. kau? [you?, (kau) terdampar [(you) stranded], (kau) burung mati [(you) dead bird], to show his hatred, and sembahyang dan memuji (?) [praying and praising (?)], di sisi sangkar (beside cage), to show his mockery besides his hatred against his ex-lover.

The core ideologies regret $\rightarrow$ awareness $\rightarrow$ hatred in the poem Kabar dari Laut are interesting to have been found out and to be re-interpreted. To start with, we can re-observe the main finding of core ideologies along with the poem Kabar Dari Laut [regret $\rightarrow>$ awareness $\rightarrow$ hatred]. We can see that now the title of the poem is made parallel with its revealed core ideologies. The sign [.....] is to show that ideology is a variant of meaning in the mind of the author, while the title Kabar dari Laut are the expressions used by the author, probably written out or spoken up. Some questions may arise here. Is the expression Kabar [news] is really news? Does the expression laut (the sea) really refer to the sea? And are the expressions Kabar dari Laut [news from the sea] really some news, good or bad, from the sea? Is Chairil Anwar a sailor? Is he happy? Is he sad? If not about news and the sea, what is the poem probably about? These are questions to answer in the next discussion.

First, we know for sure that Chairil Anwar is a literary worker, a poet, definitely not a sailor. Chairil Anwar has so far been noted as a wild animal [binatang jalang], whose passion is not easily conquered by the public or even by the government. And so is this poem, which is multi-interpreted.

This poem is a good metaphor for the author's wild passion. He is broken-hearted, along with his feelings of regret, awareness, and hatred. Chairil Anwar has smartly used the expression Kabar instead of Berita, to represent his beliefs, personal or probably private, which is then an informal word. The appearance of news [berita] is a formal one. He has also employed the expression on the sea to represent the world, or this life, which life is broad or vast, not merely between stern and steer [hidup berlangsung antara buritan dan kemudi] and the limit of it invited memory sheer [pembatasan cuma tambah menjatuhkan kenang]. Chairil Anwar has also used the metaphor Laut in this poem, not the land: at home, on the streets, at public spaces, or others, probably because he is aware of the fact that Indonesia is a maritime country with a bigger percentage on waters or seas than on land. He has rarely used the sea topic in all his works or poems. It is a probable reason for the title, besides the vast entity of the sea on earth. He has also used the sailor metaphor, probably due to the facts that a sailor usually faces hard and tough lives in the ocean, and they survive! Chairil Anwar wants to show the world that he has also survived a severe heart-break while enduring his sad memories and bad realities through hardship, i.e., sendiri di laut pilu, berujuk dengan tujuan biru, luka lebar mengeluar darah for the metaphors of loneliness, uncertainty, bad conditions respectively. However, Chairil Anwar also tries to eliminate his hardship by reviving his wild love memory, i.e., di bekas dulu kau cium napsu dan garang [in the past you kissed lust and fierce] or drinking liquor to compensate his misery], i.e. Dan tawa gila pada whiskey tercermin tenang [and crazy laughter at whiskey is reflected calmly]. 
This poem of Kabar Dari Laut has also taught us a lesson or a good experience that whatever happens to us is basically a cycle of ideologies. The three core ideologies, i.e. regret, awareness, and hatred, may be experienced by anyone in this world. We can do something stupid or wrong, regret it, be aware of it, and - this is the antithesis - forget and forgive it. Chairil Anwar has, oppositely, taught us to regret it, be aware of it, and hate it.

\section{Conclusion}

Based on the exploration on the 1946 poem Kabar Dari Laut by Chairil Anwar, the core ideologies revealed through the interpretive techniques in the coding analyses are regret $\rightarrow$ awareness $\rightarrow$ hatred, which have been inductively-analyzed from various doctrines in the poem. The main expressions Kabar and Laut are central in this poem. This interpretive exploration has found out the ideologies in the word kabar [news, or, rather say, story] and the ideologies in the word laut (the sea) and how the two sets of expressions speak out the restlessness of the noted poet Chairil Anwar. The research findings have shown that the News and the Sea have been used by the broken-hearted author to speak out his regret, awareness, and hatred due to his broken-hearted soul upon his ex-lover in the past. The sea signifies the author's small self to face and live in this large life. A good lesson for us as an antithesis, the author's hatred against his ex-lover has remained sad memories and bad realities that still live in his present time.

\section{References}

Barthes, Roland. Mythologies, a translation by Annette Lavers 1972. France: Les Lettres Nouvelles, 1957.

Bohm, A. "Theoretical Coding: Text Analysis in Grounded Theory". In Flick, U., Kardoff, E. \& Steinke, I. eds. A Companion to Qualitative Research. London: SAGE Publications, 2004: 270-275.

Caesar, M. Eco, Umberto Eco: Philosophy, Semiotics, and the Work of Fiction. Oxford: WileyBlackwell, 1999.

Cambridge. Cambridge Dictionary, https://dictionary.cambridge.org/dictionary/english. Accessed on 15 June 2018.

Eco, Umberto. A Theory of Semiotics. Bloomington: Indiana University Press.

Huppatz, D.J. "Roland Barthes, Mythologies". Design and Culture 3, 1 (2011): 85-100.

Jassin, H.B. Angkatan 45. Jakarta: Jajasan Dharma, 1972.

Jassin, H.B. Kesusastraan Indonesia Modern dalam Kritik dan Esei. Jakarta: Gunung Agung, 1967.

Merriam-Webster. Merriam-Webster's Dictionary of Synonyms. New York: Merriam-Webster Inc., 1968.

Saladana, J. The Coding Manual for Qualitative Researchers. London: SAGE Publications Ltd., 2012.

Stevenson, A. Oxford Dictionary of English. Oxford: Oxford University Press, 1968.

Strauss, A. and Corbin, J. Basics of Qualitative Research: Grounded Theory Procedures and Techniques. California: Sage Publications, 1990. 